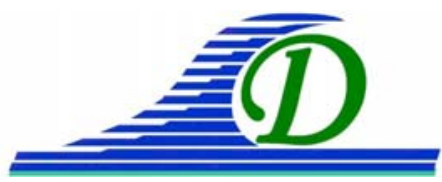

XIII ${ }^{\text {èmes }}$ Journées Nationales Génie Côtier - Génie Civil Dunkerque, 2-4 juillet 2014

DOI:10.5150/jngcgc.2014.086 C Editions Paralia CFL

disponible en ligne - http://www.paralia.fr - available online

\title{
Coastal management in The Netherlands, from past developments to future perspectives
}

\author{
KEYNOTE LECTURE - LECTURE SPÉCIALE
}

\section{Frank VAN DER MEULEN ${ }^{1}$, Rien VAN ZETTEN ${ }^{2}$}

1. Associate professor emeritus of Integrated Coastal Zone Management at UNESCOIHE and Deltares, The Netherlands. frank.vandermeulen@hetnet.nl

2. Dutch Ministry of Environment and Infrastructure, The Netherlands. rien.van.zetten@rws.nl

\section{Main coastal characteristics}

The Netherlands occupy a small low lying country $\left(35000 \mathrm{~km}^{2}\right)$ in the Delta of main European rivers, Rhine, Meuse and Scheldt. This has put coastal management always high on the national policy agenda. The coast (ca $330 \mathrm{~km}$ long) consists mainly of sandy beaches and dunes and estuaries. There are a few hard parts, where dikes, storm surge barriers and sluices are found (Fig. 1).

In the past 6000 years sea level has been rising and flooding and erosion ware prevalent. Dunes were also formed. The present prominent, so called Younger Dunes, date between 1000-1600 AD. Since 1900 to 2000 average sea level rise, based on measurements, measures appr. $18 \mathrm{~cm} / 100 \mathrm{yr}$. Due to climate change the sea level rise is expected to increase again. Predictions differ from 30-80 cm for the coming 100 year.

The coast fulfills a number of important functions for the population of the Netherlands. They are: coastal defense, recreation, nature conservation and drinking water production. Coastal defense has always been primary, but in the course of time other functions gained importance.

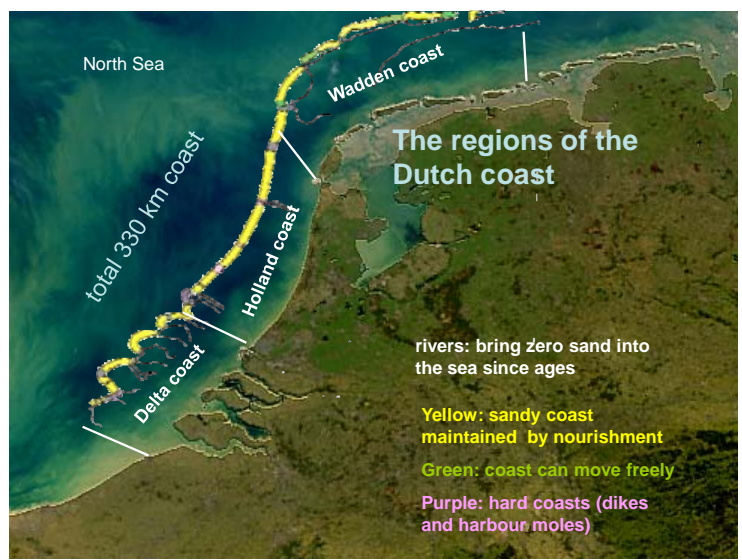

Figure 1. Physiographic regions of the Dutch coast (picture drawn by Bert van der Valk, Deltares). 


\section{Brief management history}

Retreat. In the past decades, national coastal management has shown important changes. They were a result of changes in society and in civil engineering concepts. Reactive management changed into anticipative, looking ahead into the future. Line defense changed into an integral view of the wider, entire coastal zone. In the past 50-75 years we can distinguish evolving subsequent management approaches.

Until the 1950-ies, management concentrated on how to counteract erosion, solutions differing from place to place. Hard options like groins and other concrete structures were common. However, in general the coastline was receding all over the country. Some coastal towns even completely disappeared (for example, Fig. 2).

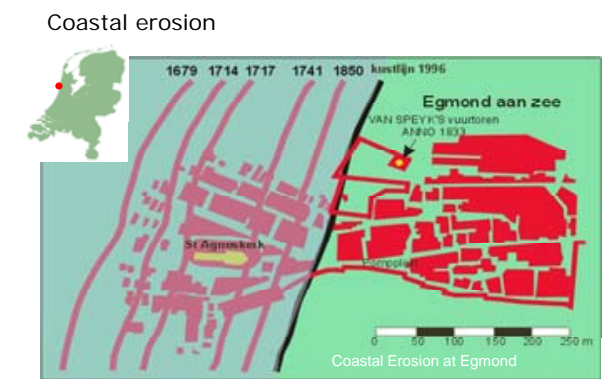

Figure 2. Coastal erosion at Egmond 1679-1996.

Note position of old town and church and present town.

Since the disastrous flood in 1953, a rigid policy of defense and "hold the line" was applied. Mainly hard civil engineering constructions were used with the sole function to defend the country against water by shortening the coastal line. Meanwhile the sandy coast remained withdrawing.

Hold the line. The first national coastal policy document (1990) investigated the effect of continuation of this process, or stopping it, or even try to built out the shore again. It was decided to fix the position of the coast not allowing any further erosion. Hard solutions were replaced by "soft" sand nourishments all over (ca $12 \mathrm{Mil} \mathrm{m}^{3} / \mathrm{yr}$ ). This policy was called "dynamic preservation" or dynamic control, allowing more fluctuation, but within boundaries.

Between 1990-1995 the policy was evaluated and dynamic preservation was adopted as national coastal policy. At the same time ecology (Fig. 3) became an important part of the discussion as well as recreation and "quality" of the coast and coastal towns. Coastal management became an integral effort, looking for the right balance between different functions. 


\section{XIII ${ }^{\text {èmes }}$ Journées Nationales Génie Côtier - Génie Civil \\ Dunkerque, 2-4 juillet 2014}



Figure 3. An artificial breakthrough of the front dunes to stimulate ecological diversity (sea water can enter from time to time) and nature values in the dunes. First example of dynamic management. De Kerf 1997.

Advance. From 2000 onwards the policy includes "care for the coastal foundation", which is defined as a broad zone including the dunes, beaches and foreshore (as far as $20 \mathrm{~m}$ bathymetry, which is more or less equivalent to a $20 \mathrm{~km}$ zone from the shore). To be solid and safe in the longer run, loss of material in this zone should be avoided. Instead of defense against water, the focus shifted to sand/sediment budgeting. This opened the way to what is called "building with nature". One of the recent examples of this is the Sand Motor, a huge beach and foreshore nourishment $\left(20 \mathrm{mil} \mathrm{m}^{3}\right)$ near The Hague, that is expected to feed the coast for 10-20 years to come (Fig. 4).



Figure 4. The Sand Motor near The Hague. High tide left, low tide on the right. Long shore transport is from south to north (towards the bottom of picture).

The newest national policy document Deltaprogram (2014) looks ahead towards 2100. It focuses on how to anticipate what likely can be expected. This is based on economic scenarios and climate scenarios and adaptive pathways. At present ca. $12 \mathrm{mil} \mathrm{m}^{3} / \mathrm{yr}$ is nourished (excluding the so called "weak link" areas) (see Fig. 5). To adapt to sea level rise of $65 \mathrm{~cm} /$ century this will do. Careful monitoring will be done to see when and how much up scaling is needed. Discussions are ongoing. 




Figure 5. Volumes of nourishment between 1991-2008 (left axis) and \% exceedance of basic coastline (right axis) for the entire coast. Yellow=beach, blue=fore shore, red dots and line $=$ exceedance basic coast line.

\section{References}

This paper was compiled on the basis of documents published by the Ministry of Infrastructure \& Environment, formerly the Ministry of Roads, Public Transport and Water Management. 